\title{
Learning Videos Increase Students' Cognitive Learning Outcomes on Animal Life Cycle Materials
}

\section{Indria Adi Kuncoro' ${ }^{1}$ Yulia Maftuhah Hidayati2}

\footnotetext{
1,2 Universitas Muhammadiyah Surakarta, Surakarta, Indonesia
}

\section{ART ICLE INF O}

Article history:

Received April 10, 2021

Revised April 12, 2021

Accepted May 03, 2021

Available online May 25, 2021

Kata Kunci:

Hasil Belajar, Media, Video

Tutorial

Keywords:

Learning Outcomes, Media,

Tutorial Video

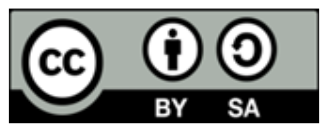

This is an open access article under the CC BY-SA license.

Copyright (ㅇ) 2021 by Author. Published by Universitas Pendidikan Ganesha.

\begin{abstract}
A B S T R A K
Media pembelajaran memiliki peran penting dalam pelaksanaan pembelajaran di era globalisasi saat ini. Oleh karena itu, diperlukan suatu media pembelajaran interaktif yang dapat meningkatkan hasil belajar siswa. Penelitian ini bertujuan untuk meningkatkan hasil belajar kognitif siswa pada materi daur hidup hewan dengan menggunakan video pembelajaran materi daur hidup hewan pada siswa kelas IV. Penelitian ini merupakan penelitian tindakan kelas (PTK) yang mengadaptasi model PTK dari Kemmis dan McTaggart. Subjek dalam penelitian ini adalah siswa kelas IV yang berjumlah 33 siswa. Pengumpulan data dilakukan dengan menggunakan instrumen berupa tes kognitif hasil belajar. Data yang telah terkumpul selanjutnya dianalisis menggunakan metode deskriptif komparatif, yaitu dengan membandingkan hasil dari tahap pra siklus dengan siklus II. Hasil penelitian menunjukkan bahwa nilai rata-rata siswa pada pra siklus adalah 72 (33\%) dan rata-rata pada siklus I adalah 80,30 (76\%) dan rata-rata siklus II adalah 91,21 (90\%). Berdasarkan hasil tersebut dapat disimpulkan bahwa penggunaan video pembelajaran dapat meningkatkan hasil belajar kognitif siswa pada materi daur hidup hewan.
\end{abstract}

\begin{abstract}
A B S T R A C T
Learning media has an important role in the implementation of learning in the current era of globalization. Therefore, we need an interactive learning media that can improve student learning outcomes. This study aims to improve students' cognitive learning outcomes on animal life cycle material using video learning on animal life cycle material for fourth grade students. This research is a classroom action research (CAR) which adapts the CAR model from Kemmis and McTaggart. The subjects in this study were grade IV students, totaling 33 students. Data was collected using an instrument in the form of a cognitive test of learning outcomes. The data that has been collected is then analyzed using a comparative descriptive method, namely by comparing the results from the precycle stage to the second cycle. The results showed that the average score of students in the precycle was $72(33 \%)$ and the average in the first cycle was $80.30(76 \%)$ and the second cycle average was $91.21(90 \%)$. Based on these results, it can be concluded that the use of learning videos can improve students' cognitive learning outcomes for animal life cycle materials.
\end{abstract}

\section{INTRODUCTION}

The learning process causes a process of testing strategies and plans that allow the emergence of learning actions in students (Killian \& Bastas, 2015; Yu \& Mohammad, 2019). Educational interaction must describe a two-way active relationship with a number of knowledge as the medium, so that the interaction is a meaningful and creative relationship. All elements of educative interaction must proceed within the bounds of educational goals. Therefore, educational interaction is a picture of a two-way active relationship between teachers and students that takes place in the bond of educational goals (Gani, 2019; Supriyati, 2020). Teachers must carry out many activities in educative interactions, including understanding the principles of educative interaction, preparing learning materials and resources, choosing methods, tools and teaching aids, choosing approaches, and conducting evaluations after the end of teaching activities (Ambarjaya, 2012; Astiani et al., 2018). The creation of meaningful learning is influenced by the level of student activity in the learning process. The activeness of students in learning will provide wider opportunities to acquire and understand new knowledge (Ambarjaya, 2012). The 
activity shown by students in learning will affect how much understanding and learning outcomes are obtained by students. The high level of student activity in science learning will cause students' understanding to become wider and student learning outcomes will also increase (Samadhi \& Riastini, 2017). One of the science subjects at the elementary school level is the life cycle of animals. Determine the animal life cycle and the stages that occur in the animal life cycle. The life cycle is a stage of growth and development that occurs in animals from small to adult. In learning, students will more easily understand the lesson when it is associated with problems encountered in everyday life, namely things that they can see directly. Especially when online learning like this, learning media is very important for teachers to use when learning. Animal life cycle learning is closely related to students' daily lives, so learning media is needed that teaches students to learn from the problems they encounter directly in their lives.

Based on interviews with fourth grade teachers at SD Muhammadiyah Pracimantoro Special Program for the 2020/2021 academic year, there are problems in the learning process activities, including: (1) the curriculum used in grade IV is the 2013 curriculum for the $2020 / 2021$ school year. (2) students are still confused in understanding the animal life cycle, even though the package book is accompanied by pictures and serial numbers, there are still many students who do not understand the animal life cycle, this can be seen in the learning process and the daily test scores of the animal life cycle in the pre-cycle. (3) the media used in learning activities are student textbooks and teacher handbooks and blackboards, meaning that there are no supporting media used in learning activities, especially science on animal life cycle materials at SD Muhammadiyah Pracimantoro Special Program. (4) the material taught is the life cycle of an animal or the so-called stages of animal life. (5) The KKM used at this time is 75. (6) the learning pattern used in SD Muhammadiyah Pracimantoro Special Program is independent learning from home because the learning is carried out online. Based on the gap above is the need for learning video media about animal life cycles. Therefore, teachers must use interesting learning media in each lesson.

The use of learning media in the learning process can make it easier for students to understand the material presented (Rakhman et al., 2017; Yudiyanto et al., 2020). So the media in a lesson is a mindstimulating learning material that can make it easier for students to understand a material concept. Here, learning video media is needed to improve student learning outcomes. Video is an audio-visual learning material that can be used to convey messages or subject matter and is very effective in helping the learning process, both for mass, individual, and group learning as well as additional media in the 2013 curriculum which requires students to understand clearly (Susilowati, 2017; Yuniarni et al., 2020). While learning outcomes are the abilities that students have after receiving their learning experiences. From this learning experience, there will be changes that can be proven, and measurable in the abilities or achievements experienced by students (Németh \& Long, 2012). Therefore, learning outcomes can be defined as competencies and skills possessed by students after the learning period (Boyd, 2019; Lukiyah, 2017). In simple terms, learning outcomes can be measured by the abilities of students. In general, learning outcomes can be seen in three aspects, namely cognitive, affective, and psychomotor aspects. In this study, researchers focused on the cognitive aspects of students. This cognitive domain means changes in student behavior in the area of cognition. Cognitive learning outcomes are not only a single ability but also multilevel. Figures who have made a classification of cognitive abilities and opinions are widely used by experts. Bloom divides and arranges hierarchically the levels of cognitive learning outcomes starting from the lowest and simplest, namely memorization to the highest and complex, namely evaluation. In Purwanto (2012) mentions the six levels, namely, memorization (C1), understanding (C2), application (C3), analysis (C4), synthesis (C5) and evaluation (C6) (Anderson \& Krathwohl, 2011; Fityana et al., 2017). In this study, the researcher chose to change the cognitive domain only with the consideration that this cognitive domain is the most highlighted and by the public it is often used as a parameter of one's learning success. Researchers will limit the assessment of the level of hots only.

This study is relevant to several previous studies that examined the use of audio-visual media in early childhood learning (Fitria, 2014). In addition, this study is also relevant to research that analyzes the effect of instructional video media on science learning outcomes in terms of student effectiveness (Yunita \& Wijayanti, 2017). Furthermore, this research is relevant to research on increasing motivation and science learning outcomes through an inquiry approach (Sukma, 2017). Application of process skills approach to improve science learning outcomes. Then the researchers raised about the application of learning videos to improve learning outcomes in animal life cycle materials. Learning videos can display information that cannot be seen directly by the student's sense of sight. Students can see the process of the life cycle of animals without having to see the original object directly, with videos students will also see directly the process of the life cycle of animals through an animation. Learning video media can realize the visualization of the life cycle material. So that the learning outcomes of students who use learning videos can be satisfactory and meet the KKM criteria (Agustiningsih, 2015; Elsani et al., 2019). This study aims to improve students' cognitive learning outcomes on animal life cycle material using video learning 
on animal life cycle material for fourth grade students. It is hoped that the results of this study can motivate students to be actively involved and interested in the teaching and learning process so that students' enthusiasm for learning can be pumped and the impact of learning outcomes is getting better. As well as being an alternative solution to learning problems in science learning on animal life cycle material.

\section{METHOD}

The type of research used in this research is the type of action research (Action Research). CAR is carried out in the classroom to solve a problem faced by the teacher in the teaching and learning process in the classroom, this is to improve the quality and learning outcomes of students. In an effort to apply various techniques, methods or strategies in learning effectively and efficiently. The research design that will be used is Classroom Action Research. Classroom Action Research (CAR) is a process of studying learning problems in the classroom through self-reflection in an effort to solve problems by taking planned actions in real situations and analyzing any effects of the treatment (Sanjaya, 2011). This research procedure adapts the classroom action research model according to Kemmis and Taggart, which consists of (1) the planning stage; (2) the action stage (action); (3) the observation/evaluation stage; and (4) the reflection stage, then back to the planning stage, the action stage and so on so as to form a cycle. The research procedures are presented in Figure 1.

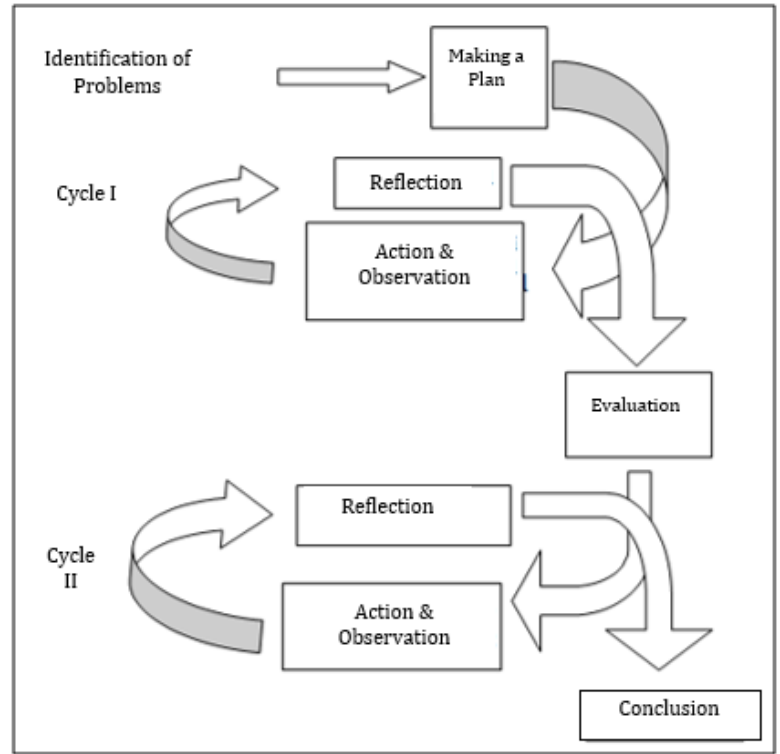

Figure 1. Basic Model of CAR Cycle According to Kemmis and McTaggart

This research was carried out in 2 cycles, where each cycle consisted of 4 meetings, from each meeting the cycle I and II experienced a gradual increase, for the first meeting to the fourth meeting, namely to see the increase in students' cognitive learning outcomes in the cycle material science map. animal life. Every meeting, the teacher gives evaluation questions to determine students' cognitive learning outcomes to evaluate learning in each lesson. The subjects of this study were the fourth grade students of SD Muhammadiyah Pracimantoro Special Program, totaling 33 students, including 21 female students and 12 male students. The research subjects were obtained using a purposive sampling technique or based on the results of observations carried out at SD Muhammadiyah Pracimantoro Special Program. The sources of data used in this study were Person (teachers, students, and principals), Place (physical condition of SD Muhammadiyah Special Program). Pracimantoro), where the Science Teaching and Learning Process takes place) and Papers (documents and notes) related to the science learning process.

The data collection technique in this study used a written test in the form of multiple choice, filling; Observation is carried out with an observation process carried out by researchers by taking an object observed in a study. Analysis of the data used with qualitative data analysis to analyze data based on the results of observations that have been carried out and media in product development, analysis of research data to be followed up in the form of evaluations given to students, as well as descriptive analysis to describe the data generated from the described research. according to the data that has been collected. The data that has been collected will be tested for verification using peer and member discussions. The 
validity of the data used in this study used triangulation of sources, namely using the same technique and different sources by comparing the learning outcomes of one student with another. The data analysis techniques used in this classroom action research include: (a) the data from the questionnaire, presenting the data by describing it in the form of exposure to the questionnaire data and concluding the data obtained. (b) The conclusion of the data from the observations of teachers and students is done by looking at the observation sheet that has been filled out by the observer during the learning process and the corrective comments from the observer. (c) Student learning outcomes can be seen from the results of the evaluation tests given at the end of each meeting.

\section{RESULT AND DISCUSSION}

\section{Result}

\section{Description of Pre-Cycle Data}

Before carrying out the learning cycle I and cycle II, the first step was to conduct observations and interviews to find out what were the problems in the fourth grade of SD Muhammadiyah Pracimantoro Special Program, especially in science subjects. With the action of observation, researchers can find out the classroom situation in the learning process before using instructional video media during online learning. From the results of these observations that there are some students who often daydream when the teacher explains or explains, in learning students do not fully understand the material given, and when the teacher asks students to work on the questions the students do not read correctly the questions and questions correctly so that it has an impact on student learning outcomes.

\section{Comparison of Average Learning Outcomes in Each Cycle}

Class Action (CAR) which was carried out in two cycles obtained data from the research results of cycles I and II that there was an increase in the learning outcomes of fourth grade students of SD Muhammadiyah Pracimantoro Special Program. The data recap of the fourth grade science learning outcomes of SD Muhammadiyah Pracimantoro Special Program which has increased can be seen in the Table 1.

Table 1. Results of Mastery Learning Science Subjects for Pre-Cycle Animal Life Cycle, Cycle I, and Cycle II

\begin{tabular}{|c|c|c|c|c|c|c|c|}
\hline \multirow{2}{*}{ No } & \multirow{2}{*}{ Category } & \multicolumn{2}{|c|}{ Pre cycle } & \multicolumn{2}{|c|}{ Cycle 1} & \multicolumn{2}{|c|}{ Cycle 2} \\
\hline & & $\mathbf{F}$ & $(\%)$ & $\mathbf{F}$ & $(\%)$ & $\mathbf{F}$ & $(\%)$ \\
\hline 1. & Complete & 11 & $33 \%$ & 25 & $76 \%$ & 30 & $91 \%$ \\
\hline 2. & Not Completed & 22 & $67 \%$ & 8 & $24 \%$ & 3 & $9 \%$ \\
\hline & Average & \multicolumn{2}{|c|}{72,72} & \multicolumn{2}{|c|}{80,30} & \multicolumn{2}{|c|}{91,21} \\
\hline & Top Highest Score & \multicolumn{2}{|c|}{100} & \multicolumn{2}{|c|}{100} & \multicolumn{2}{|c|}{100} \\
\hline & Lowest Value & \multicolumn{2}{|c|}{50} & \multicolumn{2}{|c|}{60} & \multicolumn{2}{|c|}{70} \\
\hline
\end{tabular}

Based on Table 1, it can be concluded that there is an increase in learning outcomes, this can be seen from some students who have scored above the KKM. This is proven before taking action, there are 22 students or $33 \%$ of student learning outcomes in the thematic content of science subjects, animal life cycle material in the complete category. After the action was carried out using learning video media in the first cycle, it could be seen as many as 25 students or $76 \%$ with an average value of 80.30 . While in the second cycle there were 30 students or $91 \%$ with an average value of 91.21 . So it can be concluded that the level of success achieved has met the standard performance indicators that have been set with $90 \%$ results.

\section{Discussion}

The use of learning video media in learning activities has a positive influence, especially on student learning outcomes in cognitive aspects. Cognitive aspect is the intellectual ability of students in thinking, knowing and solving problems. All efforts related to brain activity are included in the cognitive domain (Anderson \& Krathwohl, 2011; Jensen et al., 2014). Cognitive learning outcomes are behavioral changes that occur in the area of cognition. The average student learning outcomes in the cognitive aspect who participate in learning using video are increasing in each cycle. The results of research conducted by researchers in fourth grade students of SD Muhammadiyah Pracimantoro Special Program using learning video media during online learning there was an increase in student learning outcomes, especially in science subjects, animal life cycle material, this can be seen from the results of cycle I and cycle II. After an action was taken in the first cycle, the learning outcomes experienced an increase. This can be seen from 
the results of the questionnaire and the evaluation results given by the researcher. In the first cycle of learning process, students' motivation in learning has started to stand out and be enthusiastic in participating in lessons, students also begin to look active in discussions to produce products that will be made. However, in the first cycle there were several obstacles, this was because there were some students who made noise when working in groups because the learning situation was carried out online and communication between students was hampered, so the class could not be controlled properly. Therefore, the teacher forms a group and relies on students who are possible to answer questions correctly. So it can be said that in the process of implementing learning there are still shortcomings, to cover these deficiencies the researcher tries to improve the next learning process in cycle II.

Meetings I, II, III, and IV in cycle II were considered very good, especially in learning outcomes. Improving learning outcomes in cycle II has reached $90 \%$ performance indicators. Student learning outcomes are very high, this can be seen from the way students listen to the explanation of the material, students have also started to be confident in asking, and answering a question. In working in groups or when given questions students are very enthusiastic, it can be seen when students have discussions with their group friends, and when delivering group answers students have delivered in a loud voice, and students can also answer questions given in good and understandable language. by another group. To build a comfortable atmosphere in the manufacture of products, researchers asked several groups to make projects outside the room, with that researchers had to pay special attention so that the learning process went well. By using learning video media, especially science subjects, animal life cycle material for class IV SD Muhammadiyah Pracimantoro Special Program makes learning very fun and enthusiastic in the learning process, this can be seen from the way students look for information about the material provided, and students are also increasingly active in learning. The development of learning media in the millennial generation is interactive media or often referred to as interactive multimedia where the process media is quite accessible digitally.

Interactive Multimedia is one of the innovation media that can improve student learning outcomes in the learning process (Damyanov \& Tsankov, 2018; Zin et al., 2013). The interactive media used in this study, namely learning videos, is very helpful in the learning process because it can make students' knowledge deeper, this model is packaged to form a group where students directly interact with students through teacher guidance. If there is something that is not clear, it can be conveyed immediately. Because here the teacher participates directly in the learning process even though it is online. This learning video media is also very helpful for students to easily remember the material presented by the teacher because by seeing the impressions displayed by the teacher accompanied by an interesting sound so that it does not make students bored with learning activities and it can be said that learning will feel interesting. In addition, because with group work students can discuss and issue student opinions to produce better products. In addition to discussing and practicing directly making products, students are also trained to speak in front of their classmates or in the school environment, so that the experiences students experience are increasing, in this model students not only seek information from textbook sources, but can seek information from classmates. or people who are in the school area, students can also learn and gain broader knowledge with varied media, such as products made, videos, PPT, and collaboration in a group. Every time there are advantages, there must be disadvantages, shortcomings in this model where students cannot be controlled properly, for example: Noise in the classroom, this is very influential in making products because students cannot concentrate or do not focus on what students are making.

This learning video media is a medium that can channel messages in the form of a summary of the material. This learning video media is included in visual media where visual media is media that displays still images. Visual media is media that involves the sense of sight (Munadi, 2013; Trianawati et al., 2020). In addition, there are two types of messages contained in visual media, namely verbal and nonverbal messages. Verbal-visual messages consist of words in written form and non-verbal-visual messages are messages conveyed into symbols. There are three characteristics of visual media, the first is visual messages that can be conveyed in the form of images, graphs, diagrams, charts and maps. The second is the distribution of nonverbal-graphic visual verbal messages delivered in the form of books and modules, comics, magazines and journals, posters and visual boards. The third is the original object and the imitation object (model). In this case the learning video media is included in the second characteristic, namely the distribution of verbal-nonverbal-graphic visual messages with the delivery of the message in the form of a visual board. A visual board is a board that can channel visual messages (Munadi, 2013; Steele et al., 2019). This is in accordance with the learning video media, where in the media there is a summary of the material to be studied. There are many advantages that students get in the learning process by using learning video media, including: (1) having an attractive design so that it can motivate 
students, (2) it is a medium or means of learning while playing, (3) increasing collaboration between students in group activities, and (4) involve students actively in learning.

The teacher's task in motivating students is to encourage, activate and move students consciously to be actively involved in the learning process. Research using instructional video media in science learning material for animal life cycles in fourth grade students of SD Muhammadiyah Special Program. The findings obtained in this study are fun learning and can increase student activity in learning. The activeness of students in learning can affect student learning outcomes. Learning outcomes are the process of giving values to the learning outcomes achieved by students with certain criteria (Renata \& Sihombing, 2016; Sudjana, 2012). In essence, student learning outcomes are changes in behavior that include the cognitive, affective and psychomotor fields. Student learning outcomes can be seen from the results of the evaluation at the end of each meeting. The willingness and attention of groups of students who use learning videos to receive subject matter is getting better. Students pay close attention to the video played by the teacher. Before using the video, students seemed less enthusiastic about participating in the lesson. Students seem less interested and bored because the presentation of the material is less varied. Then the use of video eliminates the boredom of students who have only heard lectures from the teacher. Presentation of material accompanied by animations and pictures makes students feel happy to follow the lesson.

Furthermore, when the teacher assigns students to make summaries and explanations of the material that has been studied, students appreciate the teacher more by doing the assignments given by the teacher. Students make notes and summaries as assigned because they think these notes will be useful for doing subsequent assignments because it is not possible for the teacher to always repeat the learning video playback on the same material in class. Students have better attention to the subject matter, are enthusiastic in the learning process, and are more appreciative of the tasks of the teacher. Such an attitude ultimately causes students to more easily remember the subject matter, and better understand the learning material. Based on the above, it proves that the application of learning video media is able to improve student learning outcomes in science learning for fourth grade students in the even semester of SD Muhammadiyah Pracimantoro Special Program. Improving student learning outcomes because students have a high enthusiasm for learning and participating in the learning process, the activity of observing learning videos, demonstrations of observations and group discussions is a good way of learning for students because in these activities students can manage their learning gains obtained through the teaching and learning process which provides wider opportunities for students to observe, classify, predict, apply, plan, and communicate.

In addition, the subject teacher as a facilitator always gives encouragement and appreciation to every student who can complete tasks well in groups and is able to answer questions in individual tests. The award is like giving praise, applause and thumbs up. Because with these award students will feel more appreciated so that students always want to repeat their actions. Looking at the increase in student activity and learning outcomes in science learning that applies a process skills learning approach, it can be seen that this process skills learning approach is a very positive contribution in increasing activity in the learning process and optimal student learning outcomes and is very well used in improving the quality of learning in elementary school.

The results of this study support and strengthen various previous studies, namely Elisabet et al (2019) Ari Setiasih, Ngurah Japa, Wayan Arini (2016), Isdiyanti et al (2020), Sukma (2017) it can be concluded that learning video media can improve student learning outcomes (Elisabet et al., 2019; Septiasih et al., 2016; Sukma, 2017). However, there are some differences from any previous research with this research, the current research is to improve science learning outcomes by using instructional video media for fourth grade elementary school students. This study is only to measure the cognitive aspects of students through the evaluation of learning that has been done. Based on the things that have been said above, it proves that the use of learning videos can be an alternative in overcoming the learning problems in SD Muhammadiyah Pracimantoro Special Program, especially in science lessons on animal life cycle materials. Science learning using learning videos can increase student activity, courage, and motivation in participating in the learning process. Learning videos are very appropriate for teachers to deliver abstract learning material to make it easier for students to understand.

\section{CONCLUSION}

Based on the results of classroom action research carried out for fourth grade students of SD Muhammadiyah Pracimantoro Special Program for the even semester of the 2020/2021 academic year, with the title increasing science learning outcomes by using video media for learning animal life cycle materials for fourth grade elementary school students. By using this learning video media, it can improve 
science learning outcomes for animal life cycle materials, this can be seen from 33 students only 3 students who have not met the KKM mastery. Although there are still students who have not completed, the student's score in each cycle always increases so that it is not too far from the KKM value. Thus, this research has reached the performance indicators as determined by the researcher. Based on the results of this study, teachers, especially in science subjects, can use learning video media as an alternative for further learning media.

\section{REFERENCES}

Agustiningsih, A. (2015). Video sebagai alternatif media pembelajaran dalam rangka mendukung keberhasilan penerapan kurikulum 2013 di sekolah dasar. PEDAGOGIA: Jurnal Pendidikan, 4(1), 50-58. https://doi.org/10.21070/pedagogia.v4i1.72.

Ambarjaya, B. S. (2012). Psikologi Pendidikan \& Pengajaran Teori \& Praktik. CAPS.

Anderson, L. W., \& Krathwohl, D. R. (2011). A Taxonomy for Learning, Teaching, and Assessing; A revision of Bloom's Taxonomy of Education Objectives. Addison Wesley Longman Inc.

Astiani, N., Halimah, M., \& Hidayat, S. (2018). Pengaruh Media Papan Flanel terhadap Hasil Belajar Siswa pada Pembelajaran IPS di Sekolah Dasar. PEDADIDAKTIKA: Jurnal Ilmiah Pendidikan Guru Sekolah Dasar, 5(2), 317-325. https: //ejournal.upi.edu/index.php/pedadidaktika/article/view/7149.

Boyd, L. (2019). Using Technology-Enabled Learning Networks to Drive Module Improvements in the UK OpenUniversity. Journal of Interactive Media in Education, 2019(1), 1-7. https://doi.org/10.5334/jime.529.

Damyanov, I., \& Tsankov, N. (2018). Mobile apps in daily learning activities. International Journal of Interactive Mobile Technologies, 12(6), 133-140. https://doi.org/10.3991/ijim.v12i6.9659.

Elisabet, E., Relmasira, S. C., \& Hardini, A. T. A. (2019). Meningkatkan Motivasi dan Hasil Belajar IPA dengan Menggunakan Model Pembelajaran Project Based Learning (PjBL). Journal of Education Action Research, 3(3), 285-291. https://doi.org/10.23887/jear.v3i3.19448.

Elsani, S., Nugraha, A., \& Suryana, Y. (2019). Pengaruh Media Video Siklus Hidup Hewan Terhadap Hasil Belajar Siswa Kelas IV SDN Mugarsari. EduBasic Journal: Jurnal Pendidikan Dasar, 1(2), 134-143. https://doi.org/10.17509/ebj.v1i2.26823.

Fitria, A. (2014). Penggunaan media audio visual dalam pembelajaran anak usia dini. Cakrawala Dini: Jurnal Pendidikan Anak Usia Dini, 5(2), 57-62. https://doi.org/10.17509/cd.v5i2.10498.

Fityana, I. N., Sarwanto, \& Sugiarto. (2017). Pengembangan Instrumen Penilaian Autentik Pada Pembelajaran IPA Berbasis Proyek Untuk Siswa SMP / MTs Kelas VII. Jurnal Materi Dan Pembelajaran Fisika (JMPF), 7(2), 23-27.

Gani, A. A. (2019). Interaksi Antara Pemanfaatan Media Pembelajaran Dan Gaya Belajar Terhadap Hasil Belajar Ips Terpadu. CIVICUS: Pendidikan-Penelitian-Pengabdian Pendidikan Pancasila Dan Kewarganegaraan, 6(2), 82-87. https://doi.org/10.31764/civicus.v6i2.677.

Jensen, J. L., McDaniel, M. A., Woodard, S. M., \& Kummer, T. A. (2014). Teaching to the Test...or Testing to Teach: Exams Requiring Higher Order Thinking Skills Encourage Greater Conceptual Understanding. Educational Psychology Review, 26(2), 307-329. https: //doi.org/10.1007/s10648-013-9248-9.

Killian, M., \& Bastas, H. (2015). The effects of an active learning strategy on students' attitudes and students' performances in introductory sociology classes. Journal of the Scholarship of Teaching and Learning, 15(3), 53-67. https://doi.org/10.14434/josotl.v15i3.12960.

Lukiyah, L. (2017). Efektivitas Model Pembelajaran Numbered Head Together (NHT) terhadap Peningkatan Hasil Belajar Siswa dalam Pembelajaran PKn ( Penelitian Tindakan Kelas) pada Siswa Kelas VI SDN Randuagung 05. Jurnal PTK Dan Pendidikan, 3(1). https://doi.org/https://doi.org/10.18592/ptk.v3i1.1058.

Munadi, Y. (2013). Media Pembelajaran (Sebuah Pendekatan Baru). : Gaung Persada Press Group.

Németh, J., \& Long, J. G. (2012). Assessing learning outcomes in US planning studio courses. Journal of Planning Education and Research, 32(4), 476-490. https://doi.org/10.1177/0739456X12453740.

Rakhman, K. A., Saraha, A. R., \& Sugrah, N. (2017). Pengembangan Video Penggunaan Alat Gelas Laboratorium Kimia Di Universitas. Jurnal Inovasi Pendidikan IPA, 3(2), 161. https://doi.org/10.21831/jipi.v3i2.15667.

Renata, H., \& Sihombing, E. (2016). Pengaruh Model Pembelajaran Berbasis Masalah terhadap Hasil Belajar pada Materi Listrik Dinamis. Jurnal Ikatan Alumni Fisika Universitas Negeri Medan, 4(2), 283-290.

Samadhi, N. N. N., \& Riastini, P. N. (2017). Pengaruh Pembelajaran Quantum Berbantuan Permainan dalam Pembelajaran Terhadap Keaktifan Dan Hasil Belajar Kognitif IPA Siswa Kelas V. International 
Journal of Elementary Education, 1(3), 228-237. https://doi.org/10.23887/ijee.v1i3.11888.

Sanjaya, W. (2011). Penelitian Tindakan Kelas. Kencana Prenada Media Group.

Septiasih, N. W. A., Japa, I. G. N., \& Arini, N. W. (2016). Penerapan Project Based Learning Berbantuan Video Untuk Meningkatkan Aktivitas dan Hasil Belajar IPA di SD. MIMBAR PGSD Undiksha, 4(1). https://doi.org/10.23887/jjpgsd.v4i1.7306.

Steele, P., Johnston, E., Lawlor, A., Smith, C., \& Lamppa, S. (2019). Arts-Based Instructional and Curricular Strategies for Working With Virtual Educational Applications. Journal of Educational Technology Systems, 47(3), 411-432. https://doi.org/10.1177/0047239518803286.

Sudjana, N. (2012). Penilaian Hasil Proses Belajar Mengajar. PT Remaja Rosdakarya.

Sukma, E. S. (2017). Peningkatan Motivasi dan Hasil Belajar IPA Melalui Pendekatan Inquiri pada Siswa Kelas IV SD Negeri Wonoyoso. Jurnal Penelitian Pendidikan, 34(2), 113-119. https://journal.unnes.ac.id/nju/index.php/JPP/article/viewFile/9429/113-120.

Supriyati, I. (2020). Penerapan Metode Diskusi dalam Pembelajaran Keterampilan Berbicara pada Siswa Kelas VIII MTsN 4 Palu. Jurnal Bahasa Dan Sastra, 5(1), 104-116.

Susilowati, S. (2017). Pengembangan Bahan Ajar IPA Terintegrasi Nilai Islam untuk Meningkatkan Sikap dan Prestasi Belajar IPA Siswa. Jurnal Inovasi Pendidikan IPA, 3(1), 78-88. https://doi.org/10.21831/jipi.v3i1.13677.

Trianawati, I. G. A. K., Ardana, I. K., \& Abadi, I. B. G. S. (2020). Pengaruh Model Discovery Learning Berbantuan Media Audio Visual Terhadap Kompetensi Pengetahuan IPA. International Journal of Elementary Education, 4(3), 398. https://doi.org/10.23887/jppp.v4i3.27428.

Yu, T. X., \& Mohammad, W. R. W. M. (2019). Integration of 21st Century Learning Skills (4C Elements) in Interventions to Improve English Writing Skill Among 3K Class Students. International Journal of Contemporary Education, 2(2), 100. https://doi.org/10.11114/ijce.v2i2.4498.

Yudiyanto, Hakim, N., Hayati, D. K., \& Carolina, H. S. (2020). Pengembangan Video Pembelajaran IPA Terpadu pada Tema Konservasi Gajah Berkarakter Peduli Lingkungan. Journal of Natural Science and Integration, 3(2), 187. https://doi.org/10.24014/jnsi.v3i2.8959.

Yuniarni, D., Sari, R. P., \& Atiq, A. (2020). Pengembangan Multimedia Interaktif Video Senam Animasi Berbasis Budaya Khas Kalimantan Barat. Jurnal Obsesi : Jurnal Pendidikan Anak Usia Dini, 4(1), 290. https://doi.org/10.31004/obsesi.v4i1.331.

Yunita, D., \& Wijayanti, A. (2017). Pengaruh Media Video Pembelajaran Terhadap Hasil Belajar IPA Ditinjau Dari Keaktifan Siswa. Sosiohumaniora: Jurnal Ilmiah Ilmu Sosial Dan Humaniora, 3(2), 153-160. https://doi.org/10.30738/sosio.v3i2.1614.

Zin, M. Z. M., Sakat, A. A., Ahmad, N. A., \& Bhari, A. (2013). Relationship between the multimedia technology and education in improving learning quality. Procedia-Social and Behavioral Sciences, 90, 351-355. https://doi.org/10.1016/j.sbspro.2013.07.102. 